\title{
BENTUK TANDA DALAM WACANA IKLAN ADVERTORIAL MEDIA MASSA CETAK
}

\author{
Nurhusna \\ Universitas Negeri Makassar \\ Pos-el: nurhusnanurdin@yahoo.co.id
}

\begin{abstract}
ABSTRAK
Penelitian ini bertujuan mengungkap bentuk tanda dalam wacana iklan advertorial media massa cetak. Wacana iklan advertorial dikumpulkan dengan memilih iklan advertorial dalam bentuk barang dan jasa yang terdapat di surat kabar Kompas dan Jawa Pos sebagai sumber data penelitian. Data dianalisis melalui tahapan reduksi data, penyajian data, dan menggambar kesimpulan berdasarkan teori Milles dan Huberman (1984-1994). Hasil penelitian menunjukkan bahwa bentuk tanda yang ditemukan terdiri dari penanda budaya dan penanda sosial. Penanda budaya terdiri dari (1) cara memakai produk, (2) cara memelihara dari produk. Penanda Sosial terdiri dari (1) hidup tradisonal dan (2) hidup modern. Tanda tersebut secara keseluruhan digunakan oleh pemilik modal sebagai model strategi menarik konsumen
\end{abstract}

Kata Kunci: Semiotika, Tanda, Wacana Iklan Advertorial.

\begin{abstract}
This study aims to reveal the shape of the sign in the print media advertorial ad discourse. Advertorial advertising discourse is collected by selecting advertorial advertisements in the form of goods and services contained in Kompas and Jawa Pos newspapers as sources of research data. Data were analyzed through the stages of data reduction, data presentation, and drawing conclusions based on the theories of Milles and Huberman (1984-1994). The results showed that the shape of the signs found consisted of cultural markers and social markers. Cultural markers consist of (1) how to use the product, (2) how to maintain the product. Social Markers consist of (1) traditional life and (2) modern life. The mark as a whole is used by capital owners as a strategy model to attract consumers
\end{abstract}

Keywords: Semiotic, Sign, Advertorial Advertising Discourse

\section{PENDAHULUAN}

Anggapan-anggapan yang sedikit atau banyak mengikat perbuatan seseorang dalam masyarakat atau suatu kelompok dalam masyarakat. Anggapananggapan tersebut memberi petunjuk bagaimana seseorang harus berbuat atau bertindak. Dengan kata lain, dapat diartikan sebagai patokan-patokan atau pedoman-pedoman perihal tingkah laku dan perikelakuan yang diharapkan. Kaidah dalam suatu masyarakat berupa perintah dan larangan.
Semiotika atau ilmu tanda mengandaikan serangkaian asumsi dan konsep yang memungkinkan seseorang untuk menganalisis sistem simbolik dengan cara sistematis. Linguis asal Swiss, Ferdinand De Saussure (18571913) merupakan pelopor ilmu ini (Denzin, 2009:617). Karya-karya Saussure (1915-1966), karya-karya Charles Peirce (1931) seorang ahli pragmatik asal Amerika ditambah karyakarya Charles Morris merupakan sumber utama di dalam teori semiotika. Meski semiotika mengambil model awal dari 
bahasa verbal, bahasa verbal hanyalah satu dari sekian banyak sistem tanda yang ada di muka bumi. Kode morse, etiket, matematika, musik maupun rambu-rambu lalu lintas masuk ke dalam jangkauan ilmu semiotika. Sistem tanda dapat terartikulasikan atau terhubungkan melalui berbagai macam cara, baik ketat maupun longgar. Hubungan di antara tanda-tanda tersebut pun beragam, bisa homologis, analogis, bahkan metaforis. Struktur bahasa digunakan oleh seorang semiotis sosial, struktur kelompok, kepercayaan/agama, praktik-praktik budaya, dan makna relasi sosial untuk beranalogi. Asumsi seperti ini, seluruh tindak komunikasi antarmanusia sesungguhnya merupakan tanda, teks yang harus dibaca terlebih dahulu agar dapat dimengerti maksudnya.

Tanda adalah sesuatu yang merepresentasikan atau menggambarkan sesuatu yang lain (di dalam benak seseorang yang memikirkannya). Tanda terdiri atas dua material yakni ekspresi (seperti kata, suara, atau simbol), dan konten atau isi (makna atau arti) (Hjemlev dalam Denzin, 2009:617). Sebagai contoh, bunga bakung biasanya dikenal sebagai simbol kematian, hari paskah, atau kebangkitan sedangkan asap dihubungkan dengan rokok dan dengan kanker. Keterkaitan antara ekspresi dan konten dari contoh tersebut bersifat sosial arbirter. Konsekuensinya, akan ada banyak relasi yang bisa ditarik dari hubungan antara ekspresi dan konten.

Fungsi tanda dalam analisis sosial sangat penting artinya karena tandalah (atau tanda tentang tanda) yang menghadirkan kekhususan dan mendukung relasi-relasi di tengahtengah masyarakat Guiraud (dalam Denzin, 2009:618). Pada segi-segi tertentu, kekayaan makna pada suatu tanda sering kali teredukasi oleh pengetahuan, aturan, dan kode-kode yang dipakai oleh konvensi budaya tertentu. Pemahaman tanda memerluka pengetahuan yang tidak sedikit karena tanda (terutama tanda nonverbal) kerap diabaikan atau bahkan sama sekali tidak dikenali oleh orang-orang yang menerapkannya. Inilah yang menyebabkan makna sulit dimengerti.

Kebanyakan kasus, dapat ditemukan bahwa penafsiran dari suatu simbol atau tanda tidak selalu sama/tepat atau mempunyai kemiripan pada tiap pengamat. Hal itu bisa disebabkan oleh sempitnya pengalaman atau refleksi tiap pengamat/penelaah, sehingga bisa lahir variasi yang banyak. Namun, setelah dilakukan analisa secara lebih jauh dan sulit, akhirnya mampu ditempatkan dalam sistem konsepsi yang bisa diterima masyarakat. Terutama masyarakat akademik (meskipun seharusnya bisa masyarakat secara umum baik akademis, seniman, maupun masyarakat dari berbagai bidang profesi) (Short, 2007: 207-208).

Kategori kata menjadi penanda kenyataan (sinsign) dilihat dari konsep representasi kata dalam wacana iklan advertorial dengan konteks di luarnya. Kehadiran kata dalam wacana iklan advertorial direpresentasikan dengan mengaitkan dengan konsep di luar kata tersebut, dalam hal ini adalah melihat kehadiran sebenarnya benda atau persitiwa yang ada dalam wacana iklan advertorial dengan mengaitkan antara kenyataan yang hadir dalam wacana iklan advertorial dengan kenyataan yang terjadi pada kehidupan sehari-hari. Dengan demikian, sinsign dapat dikategorikan berdasarkan representasi konsep kenyataan dalam wacana iklan advertorial dengan konsep kenyataan yang terjadi dalam kehidupan seharihari.

Perkembangan beberapa penelitian telah menelaah dari berbagai sudut pandang, yaitu penelitian dilakukan oleh Roekhan (2009) dengan judul Kekerasan Simbolik di Media Massa. Penelitian Roekhan bertujuan untuk mengkaji secara kritis kekerasan 
simbolik yang terdapat dalam media massa. Hasil penelitian Roekhan menunjukkan bahwa kekerasan simbolik dalam media massa memiliki wujud yang merupakan wujud informasi yang dipaksakan oleh media massa kepada pembaca, strategi kekerasan simbolik merupakan upaya penyembunyian informasi bias dalam teks berita, dan dampak kekerasan simbolik tidak berdampak nyata pada pembaca ideal pada penerimaan mereka dalam waktu pendek. Penelitian lain telah dilakukan oleh Dharmojo (2005) dengan judul Sistem Simbol dalam Munaba Waropean Papua. Hasil penelitian Dharmojo menunjukkan bahwa penelitian tentang sistem simbol dalam Munaba Waropean Papua ini termasuk penelitian budaya yang prosedurnya berpedoman pada pendekatan elektif hasil kolaborasi antara semiotika dengan teori hermeneutika. Dengan pendekatan elektif, penelitian ini dapat mengklasifikasikan bentuk simbol menjadi dua, yakni simbol verbal yang meliputi kata, larik, dan bait. Simbol nonverbal yang meliputi objek, tindakan, dan suara pengiring. Hasil penelitian Dharmojo meliputi bentuk simbol verbal dan nonverbal, makna simbol verbal dan simbol nonverbal, dan fungsi simbol verbal dan nonverbal. Kategori bentuk simbol verbal diambil dari prinsipprinsip bahasa sebagai simbol untuk media komunikasi dipadukan dengan prinsip-prinsip semiotika. Bentuk simbol nonverbal berangkat dari realitas bahwa Munaba selain sebagai wahana komunikasi simbol verbal juga sebagai komunikasi simbol nonverbal. Masalah ini didukung oleh kajian komunikasi nonverbal meliputi penampilan tubuh, cara berpakaian, penataan rambut, kosmetik, artefak, dan pesan yang disampaikan melalui objek atau gambar.

Iklan dalam media massa, khususnya media cetak memberikan perian yang bermacam-macam. Khusus dalam iklan advertorial, produsen mengolah sedemikian rupa setiap iklan produk yang akan diiklankan, sehingga mampu menarik perhatian konsumen untuk membeli produk tersebut. Iklan advertorial merupakan iklan berupa berita. Selain itu, iklan advertorial menampilkan gambar dari produk yang dipasarkan sebagai konteks dari iklan tersebut, sehingga detail dari produk sangat jelas. Kemunculan tanda berupa kata dalam wacana iklan advertorial memberikan makna bervariasi berdasarkan konteks yang mengitarinya. Bahasa yang digunakan adalah bahasa verbal berupa kata dan nonverbal dianggap sebagai konteks dalam menginterpretasi wacana iklan. Apabila seorang konsumen tidak mampu membaca maksud setiap kata dengan bantuan gambar sebagai konteks yang muncul pada iklan tersebut maka seorang konsumen langsung menolak atau bahkan terpengaruh terhadap produk yang dipasarkan oleh iklan tersebut. Oleh sebab itu, pengetahuan tentang tanda dibalik kata yang muncul pada iklan perlu diajarkan dan diketahui oleh masyarakat secara umum

\section{METODE PENELITIAN}

Penelitian ini bersifat kualitatif dengan orientasi teoritis model semiotika Charles Sander Peirce (1839-1914). Data penelitian ini berupa kata verbal dan nonverbal sebagai konteks yang melatarbelakangi munculnya ideologi dalam wacana iklan advertorial media massa cetak. Sumber data penelitian ini adalah Kompas dan Jawa Pos. Peneliti merupakan instrumen kunci dalam pengumpulan data dan analisis data. Penelitian ini menggunakan sejumlah instrumen pengumpulan data dan analisis data dilakukan secara induktif. Bentuk verbal berupa kata dan nonverbal berupa konteks serta kegrafikan iklan advertorial menjadi perhatian utama dalam analisis data. Teknik pengumpulan data dilakukan melalui lima tahap, yaitu (1) menentukan sumber 
data, (2) menentukan data (iklan advertorial barang dan jasa), (3) menyeleksi data mentah, (4) mengecek kecukupan data dan mengumpulkan kembali data apabila data yang terkumpul belum memadai, dan (5) menyempurnakan dokumentasi data berskala hasil. Instrumen penelitian ini adalah (1) instrumen pengumpulan data wacana iklan advertorial berupa barang dan jasa, (2) panduan analisis ciri produk, dan (3) panduan analisis kebermanfaatan produk. Analisis data dilakukan selama proses pengumpulan data dan sesudah data terkumpul dengan menggunakan tahap analisis data dari milles dan Huberman (1984-1994) (dalam Denzin, 2009) yaitu, (1) tahap reduksi data, (2) tahap penyajian data, dan tahap verifikasi.

\section{HASIL DAN PEMBAHASAN Penanda Budaya}

Pengertian budaya dalam Ensiklopedia berasal dari bahasa sansekerta yaitu buddhayah, yang merupakan bentuk jamak dari budhi (budi atau akal) diartikan sebagai hal-hal yang berkaitan dengan budi dan akal manusia. Penanda budaya merupakan tanda yang berkaitan dengan pikiran, akal budi dan hasil dalam suatu kelompok masyarakat. Berdasarkan analisis data terhadap wacana iklan advertorial, diperoleh hasil berupa penanda budaya yang terdiri atas penanda cara kerja, cara memakai, dan cara memelihara. Secara berturut-turut, analisis data diuraikan sebagai berikut.

\section{a. Cara Memakai}

Pengertian cara menurut KBBI (Pusat Bahasa, 2007:215) adalah adat kebiasaan; perbuatan (kelakuan) yang sudah menjadi kebiasaan. Pengertian memakai menurut KBBI (Pusat Bahasa, 2007:823) adalah menggunakan; mempergunakan. Penanda cara memakai merupakan tanda yang berkaitan dengan perbuatan yang menjadi kebiasaan dalam menggunakan atau mempergunakan sesuatu, seperti contoh berikut.

a) Pertama kulit wajah diolesi krem kemudian dengan memakai alat khusus, kotoran atau residu dari merkuri dan racun-racun lainnya akan terangkat. Wajah pun akan lebih bersih dan sehat. (JP Carissa 3aa)

b) Watermelon Frost in sufflat higienes karena penggunaannya cukup disemprotkan ke area dalam mulut tanpa obat itu tersentuh oleh tangan secara langsung. (JP Watermelon 3aa)

c) Untuk mengetahui secara dini kondisi liang telinga, bisa menggunakan media video otoskopi seperti yang terdapat di Pusata Alat Bantu Dengar Melawai, yang dioperasikan oleh tenaga berpengalaman. (KP Melawai 3aa)

d) Silky Beauty dikonsumsi 2-3 tablet perhari secara teratur selama 3-6 bulan dapat memberikan anda kulit yang sehat dan putih menyeluruh. (JP Silky 3aa)

Berdasarkan konteksnya, data di atas merupakan penanda cara memakai produk sebagai penanda budaya dalam wacana iklan advertorial. Kata diolesi pada data (a) merujuk pada cara memakai produk Carissa sebagai cream pemutih wajah dan merupakan kosmetik pemutih kulit; kata disemprotkan pada data (b) merujuk pada cara memakai produk Watermelon sebagai obat untuk menyembuhkan sariawan; kata media video pada data (c) merujuk pada cara memakai alat bantu dengan Melawai sebagai alat untuk mengetahui kondisi liang telinga; dan kata dikonsumsi pada data (d) merujuk pada cara memakai produk Silky sebagai obat untuk kecantikan kulit. Data tersebut merupakan penanda cara memakai sebagai penanda budaya dalam wacana iklan advertorial.

Penanda cara memakai sebagai budaya dalam produk wacana iklan advertorial memberikan pencerminan bahwa kelompok masyarakat Indonesia 
cenderung lebih menyenangi cara praktis dalam menggunakan sebuah produk.

Kelompok masyarakat memiliki kebiasaan dalam memakai sesuatu lebih senang cara yang praktis. Cara memakai produk dalam wacana iklan advertorial mencerminkan gaya pakai kelompok masyarakat sebagai wujud kebiasaan masyarakat yang senang dengan hal yang praktis. Gaya praktis dimaksudkan sebagai cara yang lebih aman dalam menggunakan produk. Hal tersebut menjadi strategi persuasif produsen dalam memengaruhi konsumen. Oleh sebab itu, cara memakai merupakan salah satu penanda budaya dalam wacana iklan advertorial yang merujuk pada kebiasaan menggunakan sesuatu.

\section{b. Cara Memelihara}

Pengertian cara menurut KBBI (Pusat Bahasa, 2007:215) adalah adat kebiasaan; perbuatan (kelakuan) yang sudah jadi kebiasaan. Memelihara menurut KBBI (Pusat Bahasa, 2007) adalah menyelamatkan; melindungi; melepaskan dari dari bahaya. Penanda cara memelihara merupakan tanda yang berkaitan dengan perbuatan yang sudah menjadi kebiasaan dalam menyelamatkan dan melindungi sesuatu dari hal yang berbahaya, seperti contoh berikut.

a) Selamatkan kulit Anda dari bahan berbahaya. Untuk informasi lebih lanjut hubungi Carissa Skin Care Jl Sunandar Priyo Sudarmo No. 31 kav. 3 Malang. (JP Carissa 3ab)

b) Perlindungan diri dan keluarga bisa Anda dapatkan via family Protection Program dari Zurich Topas Life, melalui program itu, Zurich menyediakan perlindungan yang dapat dimiliki oleh seluruh keluarga di Indonesia. (JP Zurich 3ab)

c) Dengan silky Beauty...., kulit halus, mulus, kencang, cerah, dan bebas flek hitam... bukan impian. (JP Silky 3ab) d) Gunakan cairan yang lebih ramah dan lembut pada mata, seperti unica sensitive dari AVIZOR. (KP Unica 3ab)

atas merupakan penanda cara memilihara dari produk sebagai penanda budaya dalam wacana iklan advertorial. Kata selamatkan kulit pada data (a) merujuk pada cara memelihara kulit dengan menggunakan produk Carissa sebagai cream pemutih untuk kulit wajah dan badan melalui Carissa Skin Care di Jl Sunandar Priyo Sudarmo No. 31 kav. 3 Malang; kata perlindungan diri pada data (b) merujuk pada cara memelihara diri dengan menggunakan Asuransi jiwa melalui program family Protection Program dari Zurich Topas Life; kata kulit halus, mulus, kencang, cerah, dan bebas flek hitam pada data (c) merujuk pada cara memelihara dengan menggunakan Silky Beauty sebagai obat untuk kecantikan badan; dan kata gunakan cairan pada data (d) merujuk pada cara memelihara mata dan lensa kontak dengan menggunakan cairan pembersih dari Unica Sensitive untuk penampilan nyaman, aman, dan menarik. Data tersebut merupakan penanda cara memelihara sebagai penanda budaya dalam wacana iklan advertorial.

Penanda cara memelihara sebagai tanda dalam produk wacana iklan advertorial memberikan pencerminan bahwa kelompok masyarakat Indonesia dalam kehidupannya senang dengan perawatan diri. Perawatan diri dimaksudkan sebagai salah satu cara memelihara penampilan untuk memeroleh pencitraan baik dari kelompok masyarakat. Cara memilihara dengan melakukan perawatan diri, seperti merawat kulit dengan menggunakan cream, melindungi diri dengan cara mendaftarkan diri dan kelurga menjadi anggota asuransi jiwa, mempercantik penampilan dengan cream pemutih, dan menggunakan aksesoris 
seperti lensa kontak untuk penampilan yang sempurna.

Hal tersebut merupakan kebiasaan kelompok-kelompok masyarakat Indonesia dalam melakukan perawatan dengan tujuan memelihara hidup dan menata penampilan. Oleh sebab itu, cara memelihara merupakan tanda budaya dalam produk wacana iklan advertorial. Produsen menampilkan solusi untuk memelihara hidup dan penampilan dengan tujuan untuk memengaruhi konsumen.

Berdasarkan hasil analisis data terhadap wacana iklan advertorial, diperoleh hasil bahwa penanda budaya dalam wacana iklan advertorial merupakan salah satu tanda yang bertalian dengan kaidah dalam kelompok masyarakat. Penanda budaya dalam wacana iklan advertorial memberikan cerminan bahwa produsen dalam menyajikan produk, memikirkan kepentingannya dengan cara merealisasikan kebutuhan konsumen. Kebutuhan konsumen sebagai wujud dari kebiasaan dari kelompok masyarakat secara umum. Kebutuhan konsumen tersebut berupa kebiasaankebiasaan yang dilakukan oleh kelompok masyarakat yang disajikan dalam produk wacana iklan advertorial seperti cara kerja dan cara memakai produk, serta cara memelihara diri sebagai wujud solusi dari setiap produk terhadap konsumen.

Kebiasaan-kebiasaan masyarakat secara umum seperti ingin putih dan ingin bersih untuk tampil cantik, hal tersebut diwujudkan dalam cara kerja produk; masyarakat ingin yang praktis dan aman, hal tersebut diwujudkan dalam cara memakai produk; masyarakat ingin terlindungi, ingin cantik, dan ingin tampil sempurna, hal tersebut diwujudkan dalam cara memelihara dengan menghadirkan wahana dari keinginan masyarakat. Hal tersebut sebagai norma dalam masyarakat untuk mendapatkan pencitraan diri berupa satus sosial, mempertahankan kelas sosial, dan meningkatkan sistem narsisme gaya hidup setiap individu dalam kelompok sosialnya.

\section{Penanda Sosial}

Pengertian sosial dalam Ensiklopedia adalah kata yang merujuk pada hal-hal yang berkaitan masyarakat dan kemasyarakatan. Gaya hidup sering dihubungkan dengan kelas sosial ekonomi dan menunjukkan citra diri seseorang. Gaya hidup seseorang ditunjukkan dalam variasi keputusan cita rasanya. Berdasarkan analisis data terhadap wacana iklan advertorial diperoleh hasil berupa penanda sosial yang terdiri dari penanda kelas sosial kelompok masyarakat yang terdiri atas tanda hidup tradisional dan hidup modern. Secara berturut-turut, hasil analisis data diuraikan sebagai berikut.

\section{a. Hidup Tradisonal}

\section{Pengertian hidup dalam}

Ensiklopedia adalah ciri yang membedakan objek yang memiliki isyarat dan proses penopang diri (organism hidup) dengan objek yang tidak memilikinya. Pengertian tradisonal dalam Ensiklopedia adalah kata yang berasal dari bahasa latin tradition "diteruskan atau kebiasaan" merupakan sesuatu yang telah dilakukan untuk sejak lama dan menjadi bagian dari kehidupan suatu kelompok masyarakat, biasanya dari suatu negara, kebudayaan, waktu, atau agama yang sama. Penanda hidup tradisional merupakan tanda yang berkaitan dengan keadaan hidup secara turun-temurun tentang pandangan hidup dan kepercayaan.

a) 999 weitai adalah obat herbal yang dibuat berdasarkan teori pengobatan tradisional China, menggunakan tumbuh-tumbuhan alami berkualitas tinggi. (JP Weitai 3ba)

b) Terbuat dari 14 macam kandungan tumbuhan dan buah-buahan yang berasal 
dari bahan resep turun-temurun tradisional China. (JP Watermelon 3ba)

Berdasarkan konteksnya, data di atas merupakan penanda hidup tradisonal sebagai tanda sosial dalam produk wacana iklan advertorial. Kata tradisional pada data (a) merujuk pada hidup secara tradisional melalui produk obat herbal dari China dengan merek 999 Weitai; dan kata tradisional pada data (b) merujuk pada hidup secara tradisional melalui produk Watermelon dari obat herbal China sebagai obat sariawan. Data tersebut sebagai penanda hidup tradisional sebagai tanda sosial dalam produk wacana iklan advertorial. Penanda hidup tradisional memengaruhi konsumen melalui kebiasaan masyarakat yang percaya dengan obat tradisional. Selain itu, produsen menghadirkan pengobatan tradisional untuk menandai bahwa sebagian kelompok masyarakat Indonesia masih ada yang hidup secara tradisional.

Konsep tradisional menurut Christomy (2004:190) menyatakan bahwa adanya perubahan budaya dan perkembangan oleh realisme, modernisme, dan pascamodernisme di dalam paradigma budaya diferensiasi dan de-deferiensiasi dapat menghadirkan sebuah model tentang perubahan identitas. Di dalam masyarakat tradisional, ataupun di dalam cerita rakyat, identitas selalu pasti, solid dan dianggap stabil atau mantap. Identitas dianggap memiliki fungsi dari peran sosial dan muncul karena adanya sistem tradisional (misal dari mitos-mitos) yang memberikan orientasi tentang keberadaan seseorang di dunia ini dan biasanya ditunjukkan dengan perilaku tertentu.

Di masa lalu (pada masyarakat tradisional), persoalan tentang identitas tidak pernah muncul, masyarakat menganggap bahwa identitas selalu berkaitan dengan peran dan fungsinya di masyarakat. Hidup tradisional penuh dengan keyakinan dan kesakralan setiap titik gejala yang terdapat di dalamnya.

Hidup tradisional adalah kepercayaan sebagian masyarakat melalui pandangan hidup yang bersifat turun-temurun. Seperti data di atas bahwa seorang konsumen yang mengonsumsi obat tradisional tersebut akan merasakan khasiat tradisional dari China. Kelompok masyarakat tradisional akan mudah percaya karena pandangan hidup dari kelompok masyarakat tradisional tersebut bersifat turuntemurun. Pandangan hidup tradisional dibentuk melalui produk-produk yang bersifat tradisional untuk menandai kelompok hidup tradisional. Hal tersebut menjadi salah satu strategi persuasif produsen dalam membentuk penanda sosial sebagai tanda kaidah dalam wacana iklan advertorial. Hidup tradisional diyakini oleh sebagian kelompok masyarakat memiliki khasiat yang lebih manjur dibandingkan dengan produk modern.

Oleh sebab itu, penanda hidup tradisional merupakan tanda sosial sebagai penanda kaidah dalam wacana iklan advertorial. Tataran hidup tradisional sebuah imajinasi yang diciptakan oleh produsen untuk memengaruhi konsumen dengan meyakinkan konsumen bahwa hidup tradisional itu merupakan hidup sehat dan kuat.

\section{b. Hidup Modern}

Pengertian hidup dalam Ensiklopedia adalah ciri yang membedakan objek yang memiliki isyarat dan proses penopang diri (organism hidup) dengan objek yang tidak memilikinya. Pengertian modern dalam Ensiklopedia merujuk pada sesuatu yang "terkini dan baru", dunia modern dianggap sebagai dunia yang dipengaruhi oleh praktik dan teori kapitalisme, industrialism, dan negarabangsa. Penanda hidup modern merupakan tanda yang berkaitan dengan 
kehidupan dalam keadaan baru dan mutakhir, seperti contoh berikut.

a) Matras dalam koleksi eksklusif ini didesain dan dilengkapi fitur-fitur mewah yang didukung sistem daya topang modern untuk isterahat malam yang optimal. (KP Florence 3bb)

b) Jam tangan ini tampil dengan desain modern yang direpresentasikan dari pemilihan material baja antikarat, bentuk case bulat diameter 4,5 sentimeter, fitur fungsi chronograph, dan jendela penanggalan. (KP Bonia 3bb)

Berdasarkan konteksnya, data di atas merupakan penanda hidup modern sebagai tanda sosial dalam produk wacana iklan advertorial. Kata modern pada data (a) merujuk pada hidup secara modern melalui produk Florence sebagai matras tempat tidur di kamar. Daya topang modern pada matras memberikan tanda bahwa matras tersebut sebagai tempat isterahat keluarga, harus kuat dari ketahanan. Tempat memanjakan waktu isterahat dengan orang-orang terkasih, harus mampu terkesan indah dipandang dengan model kemewahannya yang baru dan mutakhir. dan kata modern pada data (b) merujuk pada hidup secara modern melalui produk Bonia sebagai jam tangan dan merupakan alat penunjuk waktu yang digunakan sebagai aksesoris di pergelangan tangan.

Bentuk dari jam tangan sebagai penunjuk waktu untuk aksesoris tangan, banyak individu menganggap penting dalam melengkapi penampilan. Pelangkap penampilan perlu gaya dan bentuk yang mewah dan baru untuk mendapatkan efek dari individu lain yang melihatnya. Data tersebut sebagai penanda hidup modern sebagai tanda sosial dalam produk wacana iklan advertorial untuk memengaruhi konsumen. Penanda modern dihadirkan oleh produsen untuk menandai bahwa kelompok masyarakat Indonesia memiliki pandangan hidup secara modern.
Penanda modern diwujudkan oleh produsen melalui produk-produk yang terbuat dari bahan-bahan dan desain terbaru dan mewah. Penanda hidup modern menandai bahwa kelompok masyarakat memiliki kesenangan pada produk-produk yang baru dan mutakhir. Produk baru dan mutakhir diyakini oleh masyarakat memiliki standar nilai jual tinggi dan menandakan kemewahan dari setiap produk. Kelompok masyarakat yang hidup modern memiliki pandangan hidup mewah, seperti pada data di atas dari tempat tidur sampai dengan aksesoris disediakan produk yang modern. Produsen menyajikan produk modern untuk menandai kelompok masyarakat yang senang hidup secara modern.

Pandangan hidup modern merupakan kebiasaan oleh kelompok masyarakat yang menyenangi kemewahan. Hal tersebut sejalan dengan pendapat Christomy (2004:190) menyatakan bahwa masyarakat modern mengacu pada setiap bagian dari elemen budaya yang selalu ditandai dengan otonomi atau penuh dengan kemapanan. Kemapanan dan Kemewahan kelompok masyarakat modern tercermin dari produk-produk yang digunakan, baik prabot di rumah maupun pakaian dan aksesoris. Hal tersebut sejalan dengan pendapat Sobur (2006:184) menyatakan bahwa individu modern dalam budaya konsumen itu disadarkan bahwa dia tidak hanya berbicara dengan busananya, tetapi dengan rumahnya, prabotnya, dekorasi, mobil, dan berbagai aktivitas lain yang harus dipahami dan diklarifikasikan dalam kaitannya dengan kehadiran serta tidak adanya selera.

Oleh sebab itu, penanda hidup modern merupakan tanda sosial sebagai penanda kaidah dalam wacana iklan advertorial. Hidup modern diyakini oleh kelompok masyarakat memiliki kemewahan dan nilai jual tinggi. Hal tersebut merupakan salah satu strategi 
persuasif produsen dalam menarik perhatian konsumen dan mampu memengaruhi konsumen.

Pembentukan dua kutub ideologi sebagai penanda sosial dalam wacana iklan advertorial, yaitu tradisional dan modern memiliki tujuan agar masyarakat pengguna tidak bosan, dan citra ideologi suatu produksi tetap terjaga dan yang lebih penting lagi adalah nilai ekonomis bagi kepentingan masyarakat industri tetap terjaga dan menguntungkan pihak produsen (Christomy, 2004:190).

Berdasarkan hasil analisis data di atas, diperoleh hasil bahwa penanda kaidah merupakan tanda secara konvensi telah diyakini oleh kelompok masyarakat sebagai cerminan dari kebiasaankebiasaan dan pandangan hidup dari masing-masing kelompok. Penanda kaidah dalam wacana iklan advertorial terdiri dari penanda budaya dan penanda sosial. Penanda budaya mewujud cara kerja dan cara memakai produk serta cara memelihara dari kelompok masyarakat untuk mencapai hidup yang sempurna. Penanda sosial mewujud struktur sosial kelompok masyarakat yang terdiri dari hidup tradisional dan hidup modern. Penanda budaya dan penanda sosial merupakan tanda kaidah yang terdiri dari kebiasaan-kebiasaan dan pandangan hidup kelompok masyarakat dalam mencapai kehidupan yang lebih baik dan sempurna.

Hal tersebut sejalan dengan teori Eco (Zoest, 1996:44) bahwa tanda sebagai sesuatu, atas dasar konsvensi masyarakat, dapat mewakili sesuatu yang lain. Dengan mengutip pendapat Morris (1938), Eco mengatakan bahwa sesuatu itu menjadi atau dapat menjadi tanda kalau ditafsirkan sebagai tanda oleh beberapa interpretan.

\section{SIMPULAN}

Simpulan dalam penelitian ini adalah wacana iklan advertorial mewujudkan berbagai kepentingan hidup dan pandangan hidup kelompok masyarakat untuk memengaruhi masyarakat. Semakin jelaslah bahwa strategi pemasaran iklan khususnya iklan advertorial membutuhkan strategi yang kompleks dan diciptakan oleh rumah produksi/agensi kapitalisme yang berlatar budaya kontemporer. Dengan demikian, iklan dan budaya industri berjalan bersama pada budaya modern dan pascamodernisme dengan tandatanda yang berasal dari tema-tema tradisional, modern, dan pascamodernisme (Christomy, 2004:194).

Berdasarkan dari kesimpulan tersebut maka diharapkan kepada pemilik modal (pengiklan) menyajikan iklan dengan menggunakan bahasa yang sesuai dengan kenyataan supaya konsumen (masyarakat tidak dirugikan). Selain itu, diharapkan kepada pembaca agar menggunakan teknik membaca kritis dalam membaca iklan supaya tidak merasa tertipu dari bahasa iklan yang digunakan.

\section{DAFTAR PUSTAKA}

Christomy, Tommy \& Yuwono, Untung. 2004. Semiotika Budaya. Depok: Puspet Kemasyarakatan \& Budaya Direktorat Riset dan Pengabdian Masyarakat Universitas Indonesia.

Denzin, Norman K \& Yvonna S. Lincoln. 2009. Hand Book of Qualitative Research. Yogyakarta: Pustaka Pelajar.

Ensiklopedia.

(Online), (http//www.wikipedia indonesia.com), diakses 11 April 2014.

Kasali, Rhenald. 2007. Manajemen Periklanan. Jakarta: Pusat Antaruniversitas: Balai Pustaka.

Roekhan. 2009. Kekerasan Simbolik di Media Massa. Disertasi tidak dipublikasikan. Malang: PPS UM.

Short, Don Levingston. 2007. Peirce's Theory of Signs. New York: 
Cambridge UniversityPress.

Dalam (Joko Susilo. 2013. Teori

Sastra: dari Klasik Sampai

Modern Semiotik Peirce.

Surabaya: Universitas

Airlangga).

Zoest, Van AART \& Sudjiman, Panuti.

1996. Serba-serbi Semiotika.

Jakarta: Gramedia Pustaka

Utama. 